\title{
Van Bulletin naar Tijdschrift
}

\section{Inleiding}

Het eerste nummer van het Tijdschrift voor Medisch Onderwijs is er. Het Tijdschrift is de opvolger van het Bulletin Medisch Onderwijs, het tijdschrift van de Nederlandse Vereniging voor Medisch Onderwijs (NVMO). Voor nieuwe lezers is de voorgeschiedenis van dit tijdschrift en de NVMO wellicht niet bekend. In het onderstaande wordt dit verleden kort samengevat en wordt uitgelegd wat we met dit Tijdschrift willen bereiken voor lezers en auteurs.

\section{Nederlandse Vereniging voor Medisch Onderwijs (NVMO)}

De NVMO werd in 1972 opgericht met als doelstelling om een forum te creëren waar docenten en onderwijskundigen elkaar zouden kunnen ontmoeten. De ontwikkeling van de NVMO is uitgebreid beschreven in een speciale uitgave van het Bulletin Medisch Onderwijs (BMO) ter gelegenheid van het 25 -jarig jubileum in $1997 .{ }^{1}$

De NVMO is begonnen als een kleine vereniging, die in de eerste jaren van haar bestaan een stabiel aantal leden had. Het is de verdienste van het bestuur dat de NVMO de jaren zeventig en het begin van de jaren tachtig heeft overleefd. In die tijd ging het met het medisch onderwijs niet zo geweldig. Zo werden op verschillende plaatsen facultaire onderwijsdiensten gedecimeerd. Halverwege de jaren tachtig begon het aantal leden geleidelijk te groeien. Vanuit het besef dat de problemen en uitdagingen in het medisch onderwijs ook herkenbaar zijn in andere opleidingen in de gezondheidszorg is ook geprobeerd om bij deze opleidingen leden te werven.
In 1994 werd het ledenbestand van de NVMO geanalyseerd om na te gaan of verdere groei van de vereniging mogelijk was. ${ }^{2}$ Er waren toen 441 leden, waaronder 49 van wie bekend was dat zij in het hoger beroepsonderwijs (hbo) werkzaam waren. Er waren zes leden in België en vier in Duitsland. Opvallend was dat er faculteiten met veel en faculteiten met weinig leden waren. Hieruit werd toen geconcludeerd dat het aantal leden zou moeten kunnen groeien. Wat op de ene faculteit kon, zou ook op de andere faculteit haalbaar moeten zijn. Onlangs is deze analyse herhaald. Er zijn nu (in 1999) 596 leden, waarvan achttien in België, één in Duitsland en één in Suriname. In tabel 1 worden uit beide analyses de gegevens weergegeven over het ledenbestand in Nederland.

Het aantal leden uit het hbo en andere gezondheidszorgopleidingen lijkt stabiel. De grootste groei blijkt te hebben plaatsgevonden in de faculteiten die gelegen zijn in Noord- en Zuid-Holland, Utrecht en Gelderland. Bij het doorbladeren van de adressenbestanden valt op dat mensen die actief zijn in de onderwijsorganisatie van de faculteiten, vrijwel allemaal lid zijn. Het ledenbestand laat ook goed zien dat veel huisartsen (met name van landelijke verenigingen) geïnteresseerd zijn in medisch onderwijs. Wie de nationale en internationale ontwikkelingen volgt, wist natuurlijk al dat huisartsgeneeskunde op onderwijsgebied het meest actieve specialisme is. Maar ook in andere vervolgopleidingen wordt op dit moment hard gewerkt aan verbeteringen. Het gezondheidszorg- 
Tabel 1. Analyse van het adressenbestand van de NVMO. Voor zover bekend is aangegeven of de leden werkzaam zijn in een geneeskundeopleiding of in andere gezondheidszorgopleidingen.

\begin{tabular}{|c|c|c|c|c|c|c|}
\hline & \multicolumn{3}{|c|}{1994} & \multicolumn{3}{|c|}{1999} \\
\hline & Geneeskunde & $\mathrm{HBO}$ & $?$ & Geneeskunde & $\mathrm{HBO}$ & $?$ \\
\hline Noord-Holland & 65 & 17 & 7 & 120 & 13 & 4 \\
\hline Zuid-Holland & 42 & 18 & 6 & 81 & 4 & 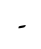 \\
\hline Zeeland & 1 & - & - & - & - & - \\
\hline Noord-Brabant & 3 & 2 & - & 6 & 10 & - \\
\hline Utrecht & 42 & 3 & 16 & 74 & 3 & 2 \\
\hline Flevoland & - & - & 1 & 1 & - & - \\
\hline Friesland & - & - & - & 2 & 2 & - \\
\hline Groningen & 78 & 2 & 1 & 77 & 1 & - \\
\hline Drenthe & 3 & 1 & 1 & 4 & 1 & 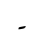 \\
\hline Overijssel & 2 & 2 & - & 8 & 1 & - \\
\hline Gelderland & 36 & 2 & 5 & 54 & 3 & - \\
\hline Limburg & 84 & 2 & 2 & 96 & 9 & - \\
\hline Totaal & 353 & 49 & 39 & 523 & 47 & 6 \\
\hline
\end{tabular}

onderwijs als geheel is in beweging. Veel medische faculteiten in Nederland werken aan een nieuw curriculum en in België worden ingrijpende curriculumherzieningen uitgevoerd. Kortom, er is genoeg te schrijven en de conclusie is ook nu dat er nog vele geïnteresseerde leden en lezers te vinden moeten zijn.

Voor de overgang van Bulletin naar Tijdschrift zijn twee activiteiten van de NVMO van bijzonder belang: het BMO en het Gezond Onderwijs Congres (GOC).

\section{Geschiedenis van het Bulletin Medisch Onderwijs}

In 1982 is het eerste BMO uitgegeven. Caspar Bleys uit Utrecht was in de beginjaren de stuwende kracht. Samen met enkele bestuursleden van de NVMO lukte het hem de eerstelingen van het Bulletin geregeld uit te geven. In 1988 nam Albert Scherpbier het eindredacteurschap over en samen met de andere redacteuren en de auteurs lukte het om viermaal per jaar een goed gevuld blad uit te geven. Douwe Buiter zorgde voor een mooie lay-out en Mereke Gorsira verzorgde de redactionele eindafwerking. In 1993, na lang beraad, besloten redactie en bestuur van de NVMO om de uitgave te professionaliseren. Het Bulletin werd ondergebracht bij uitgeverij Universitaire Pers Maastricht en Ineke Wolfhagen werd de nieuwe eindredacteur. Bij de verandering in 1993 schreef de redactie dat het haar voornemen was om van het tijdschrift een volwaardig wetenschappelijk forum voor onderzoek en ontwikkeling van het medisch onderwijs te maken. 3 of dit gelukt is, kan door de redactie zelf niet objectief beoordeeld worden. Het aantal lezers is in elk geval toegenomen, zoals eerder beschreven. Ook heeft in de periode van 1993-1998 het BMO een plaats gekregen in de bibliotheken van alle Nederlandse faculteiten geneeskunde. ${ }^{4}$ 
De overgang van Bulletin naar Tijdschrift heeft de afgelopen jaren vaak op de agenda van redactie en bestuur van de NVMO gestaan. Logisch, want het is geen gering besluit geweest. Toen ook uit de ledenvergadering spontaan vragen kwamen waarom het Bulletin niet een Tijdschrift werd, is dit opgevat als een positief signaal. Toen uitgeverij Bohn Stafleu Van Loghum bereid was om ons te ondersteunen en het Tijdschrift in hun fonds op te nemen, was het besluit snel genomen. Het nieuwe TMO zal zesmaal per jaar verschijnen. Ontwikkelingen van het GOC speelden ook een rol bij het nemen van het besluit. Hierover in het onderstaande meer.

\section{Het Gezond Onderwijs Congres}

Zoals eerder beschreven, heeft de NVMO sinds haar oprichting als belangrijkste doelstelling gehad om de uitwisseling van informatie over ontwikkeling van onderwijs en onderzoek van onderwijs te bevorderen. ${ }^{1}$ De vereniging organiseerde vrijevoordrachtendagen en themadagen om deze doelstelling te realiseren. In 1990 werd als experiment een tweedaags congres georganiseerd in Oegstgeest. Het was buitengewoon spannend of de tijd er wel rijp voor was en er genoeg belangstelling zou zijn. Het (eerste) Gezond Onderwijs Congres (GOC-0) met als hoofdorganisator Albert Scherpbier was een succes. Er waren ongeveer honderd deelnemers. Het aantal bijdragen was echter nog gering. Eén nummer van het BMO was als proceedings voldoende. $5 \mathrm{Er}$ werd door het bestuur van de NVMO besloten om door te gaan en een volwaardig congres te organiseren in de Koningshof te Veldhoven. Het eerste echte GOC vond plaats in 1991 en het resultaat werd verwoord in eigen proceedings. De eerlijkheid gebiedt te vermelden dat het besluit van het bestuur in 1990 wel een klein gokje was.
Achteraf blijkt het een hele wijze gok geweest te zijn. Sindsdien is het congres namelijk jaarlijks georganiseerd en wordt op menig boekenplank van in medisch onderwijs geïnteresseerden zo'n zeventien centimeter in beslag genomen door acht proceedings, met een interessante en gevarieerde inhoud. Waren er in 1991 ongeveer 200 deelnemers, in 1999 waren het er meer dan 400 . Het succes is te danken aan deelnemers, sprekers, auteurs, organisatoren, redacteuren en vele anderen. Niet iedereen kan genoemd worden. Geheel ten onrechte worden daarom hier alleen de hoofdorganisatoren genoemd, in chronologische volgorde: Cees van der Vleuten, Jaap Metz, Edvard Houtkoop, Jan Pols, Olle ten Cate, Ko Smal, Marian Verweij, Gerard Spaai en Roy Remmen. Het redigeren en uitbrengen van de proceedings was elk jaar weer een grote klus. Het is nooit echt duidelijk geworden hoe intensief de proceedings gelezen worden. Ongeveer de helft van de NVMO-leden bezoekt het congres en krijgt dus de proceedings. Er wordt in ieder geval regelmatig naar verwezen. Daarnaast hebben ze een belangrijke functie gehad in het Nederlandse medisch onderwijs als stimulans om steeds meer op te schrijven. De "credit" voor deze cultuurverandering komt toe aan de auteurs van artikelen in de proceedings. De verschillende redactieleden verdienen ook "credit", omdat zij de auteurs hebben geholpen de artikelen publicabel te maken. Zoals het een modern docent betaamt, functioneerden de redactieleden als facilitator en coach. Hetgeen net als bij docenten - niet wil zeggen dat alles geaccepteerd werd, maar wel dat het uitgangspunt was dat de boodschap zo goed mogelijk verwoord moest worden.

In het kader van de verandering van Bulletin naar Tijdschrift hebben de Werkgroep GOC en de redactie van BMO gezamenlijk besloten om de auteurs van artikelen voor de proceedings van GOC-9 
te vragen hun kopij in te leveren bij de redactie van TMO. De voornaamste reden van dit besluit is dat we alleen gezamenlijk een draagvlak hebben voor een goede inhoud van een vaker uitkomend tijdschrift. Het bestuur van de NVMO accordeerde de koerswijziging. In plaats van proceedings zal de Werkgroep GOC een van de nummers van TMO redigeren, dat grotendeels gevuld zal worden met artikelen van sprekers op het GOC. Daarnaast staan uiteraard in alle volgende TMO's artikelen afkomstig van het GOC.

\section{Het Nederlands Tijdschrift voor Medisch Onderwijs}

De redactie wil met het Tijdschrift de oorspronkelijke doelstelling van de NVMO blijven ondersteunen: het creëren van een forum waar docenten en onderwijskundigen elkaar "ontmoeten". Om discussie te stimuleren worden de rubrieken "Forum" en "Ingezonden" ingevoerd. Hierin wordt aandacht besteed aan actuele onderwerpen en controversen in het medisch onderwijs. Naast artikelen over onderzoek van onderwijs en overzichtsartikelen worden ook beschrijvende artikelen uit de medische onderwijspraktijk opgenomen. Om de lezers de mogelijkheid te bieden om zich te oriënteren op de internationale literatuur worden in elk nummer van TMO referaten opgenomen. Binnenkort wordt gestart met een serie "Bespreking medische studieboeken". Samenvattend, kan er veel: het "woord" is eigenlijk aan de auteurs. De redactie is van mening dat er voldoende lezerspotentieel is om de auteurs de kans te geven dat hun artikelen goed gelezen zullen worden. Wat kunnen zij verwachten van de redactie? Op de eerste plaats worden alle artikelen gereviewd met de bedoeling om de boodschap van de auteur zo goed mogelijk uit de verf te laten komen. Vanuit de redactie zal het verzamelde commentaar naar de auteur gestuurd worden met zo concreet mogelijke suggesties voor verbetering.

Of een en ander lukt, moet natuurlijk nog blijken. De nieuwe redactie is klaar voor deze nieuwe ontwikkelingsfase en meent dat we in het Nederlandse taalgebied toe zijn aan een volwassen Tijdschrift voor Medisch Onderwijs.

\section{Literatuur}

1. Themanummer NVMO 25 jaar. Bulletin Medisch Onderwijs 1997;16(1):1-64.

2. Redactioneel. Bulletin quo vadis? Bulletin Medisch Onderwijs 1994;13(2):49-51.

3. Redactioneel. Tijdschrift of Bulletin? Bulletin Medisch Onderwijs 1993;12(1):1.

4. Hylkema N, Prince CJAH, Scherpbier AJJA, Vleuten $\mathrm{CPM}$ van der. Is de informatie over medisch onderwijs bekend en wordt het gebruikt? Bulletin Medisch Onderwijs 1999;18(2):74-9.

5. Scherpbier AJJA, Metz JCM, Vleuten CPM van der, redactie. Proceedings Gezond Onderwijs. Bulletin Medisch Onderwijs 1991;10(2):41-80.

\section{De Redactie}

